\title{
PENERAPAN TEKNOLOGI ENERGI TERBARUKAN MELALUI MODEL SCIENCE TECHNO PARK DI DESA KIAMA KEPULAUAN TALAUD
}

\author{
Meita Rumbayan ${ }^{*}$ \\ Sherwin Sompie ${ }^{2}$ \\ Rilya Rumbayan ${ }^{3}$ \\ ${ }^{1 * 2}$ Jurusan Teknik Elektro Fakultas Teknik Universitas Sam Ratulangi, Manado, Indonesia \\ ${ }^{3}$ Jurusan Teknik Sipil, Politeknik Negeri Manado, Indonesia \\ meitarumbayan@unsrat.ac.id ${ }^{1 *}$ \\ aldo@unsrat.ac.id ${ }^{2)}$ \\ rilya.rumbayan@gmail.com ${ }^{3}$
}

\author{
Kata Kunci: [Teknologi \\ Tepat Guna, Energi \\ Terbarukan, Science Techno \\ Park, Kepulauan Talaud]
}

\begin{abstract}
Abstrak: Latar belakang program pengabdian masyarakat ini sebagai hilirisasi hasil riset berbasis teknologi energi terbarukan untuk masyarakat pesisir dan pulau perbatasan yang mengalami masalah krisis energi listrik di desa Kiama Kabupaten Kepulauan Talaud. Metode pengabdian masyarakat ini adalah (1) Penerapan teknologi tepat guna berbasis energi terbarukan melalui model Science Techno Park sebagai sarana diseminasi bagi masyarakat mitra; (2) Diseminasi teknologi tepat guna berbasis energi terbarukan berupa energi matahari, energi angin dan energi biomass (3) Pendampingan dan pelatihan teknologi tepat guna yang diterapkan bagi masyarakat di desa mitra. Hasilnya, melalui transfer teknologi dalam kegiatan Program Pengembangan Desa Mitra (PPDM) adalah penerapan teknologi energi terbarukan yang terintegrasi di lokasi science techno park skala kecil dan tersebar di beberapa lokasi fasilitas umum sebagai contoh TTG yang terdiri dari 4 unit pembangkit listrik tenaga surya off-grid, 2 unit contoh pembangkit listrik tenaga angin skala kecil, dan 1 unit pembangkit listrik tenaga biogas skala rumah tangga. Melalui program pengabdian masyarakat ini diharapkan implementasi teknologi energi terbarukan terus berkelanjutan melalui transfer teknologi kepada kelompok masyarakat mitra.
\end{abstract}

Published by:

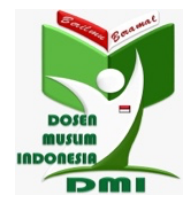

Copyright (C) 2021 The Author(s)

This article is licensed under CC BY 4.0 License

\section{(cc) $\mathrm{BY}$}

https://dmi-journals.org/jai 


\section{Pendahuluan}

Potensi desa Kiama yang terletak di pesisir pantai pulau Talaud memiliki banyak alasan sehingga lokasi ini dipilih untuk pelaksanaan Program Pengembangan Desa Mitra (PPDM) dengan judul "Program Pengembangan Desa Mitra Di Kiama Kabupaten Kepulauan Talaud Menjadi Sentra Science Techno Park Energi Terbarukan dan Rumah Tahan Gempa. Pertama, telah ada kerjasama antara pemerintah desa Kiama, kelompok mitra yang merupakan penduduk desa Kiama dengan Tim PPDM Universitas Sam Ratulangi. Kerjasama dilakukan saat Tim melakukan penelitan berupa pengujian model infrastruktur energi listrik untuk masyarakat kepulauan dengan mengambil lokasi Desa Kiama sebagai studi kasus.

Kedua, Desa Kiama telah disurvey oleh Tim pelaksana memiliki potensi energi terbarukan berupa energi surya, energi angin dan energi biomass yang dapat dimanfaatkan untuk sumber energi bagi masyarakat pulau terdepan dan terpencil yang mengalami masalah keterbatasan akses listrik. Ketiga, sumber daya manusia di desa Kiama dari pemerintah desa sampai pada penduduk desa yang terdiri dari kelompok petani dan nelayan (mitra 1) dan kelompok pemuda desa dan perempuan desa (mitra 2) sangat mendukung Tim dalam program kegiatan yang telah dilakukan berupa penelitian studi kasus dan program pengabdian masyarakat yang merupakan hilirisasi penelitian Tim di bidang penerapan energi terbarukan.

Kondisi sosial masyarakat yang mengalami keterbatasan akses listrik karena kondisi geografisnya yang merupakan daerah remote di pulau terdepan perlu mendapat perhatian khusus dan pengembangan dari Tim PPDM sebagai hilirisasi penelitian teknologi tepat guna energi terbarukan bagi masyarakat setempat.

Ada 2 macam permasalahan prioritas yang perlu ditangani di desa mitra yaitu: (1) Krisis energi listrik yang dialami masyarakat berupa pemadaman listrik dari jaringan sehingga tidak bisa menyuplai kebutuhan energi listrik masyarakat secara kontinu. (2) Keterbatasan pengetahuan masyarakat terhadap teknologi tepat guna energi terbarukan berupa energi surya, energi angin dan energi biomass.

Desa Kiama yang terletak di Pulau Karakelang menjadi desa mitra untuk pengembangan Sentra Science Techno Park Berbasis Energi Terbarukan yang memiliki potensi energi surya, energi angin dan energi biomass. Desa ini terletak di pulau perbatasan yang mengalami masalah keterbatasan akses listrik. Keterbatan akses listrik ini disebabkan oleh ketersediaan listrik yang tidak secara kontinu 24 jam dan seringnya terjadi pemadaman listrik baik siang maupun malam dialami oleh masyarakat di pulau ini. Penerapan energi terbarukan diyakini bisa menjadi solusi untuk permasalahan kebutuhan energi listrik yang dialami masyarakat kepulauan (Rumbayan, 2018). Hilirisasi hasil penelitian teknologi energi terbarukan bagi masyarakat kepulauan sudah dikembangkan dan dipublikasikan oleh Tim pelaksana (Rumbayan, 2021).

Dampak sosial yang positif dengan adanya pemanfaatan energi terbarukan di daerah pedesaan sudah dilaporkan di Bangladesh (Khan \& Azad, 2014). Pengalaman pelaksanaan kegiatan pengabdian masyarakat yang sudah dipublikasikan tim pelaksana sebelumnya ada dalam jurnal Penelitian dan Pengabdian Ethos (Sains \& Teknologi) dengan judul "Introduksi Teknologi Biogas Sebagai Energi Terbarukan untuk Masyarakat Pedesaan" (Rumbayan, 2017) dan "Penerapan Pembangkit Listrik Tenaga Surya Skala Rumah Sederhana di Desa Lahopang Kabupaten Sitaro Provinsi Sulawesi 
Utara" (Rumbayan, 2018). Kegiatan pelaksanaan pengabdian masyarakat oleh Tim pada tahun 2019 dipublikasikan pada seminar pengabdian masyarakat di Politeknik Ujung Pandang (Rumbayan dkk, 2019). Kegiatan pengabdian masyarakat oleh Tim pada tahun 2020 dipublikasikan di jurnal pengabdian masyarakat SHARE Petra (Rumbayan dkk, 2020) dan jurnal pengabdian masyarat JPM (Rumbayan dkk, 2020).

Tujuan kegiatan PPDM ini adalah:

1. Pembangunan Science Techno Park Berbasis Energi Terbarukan di desa mitra sebagai model tempat diseminasi dan sosialisasi teknologi tepat guna bagi masyarakat.

2. Introduksi dan diseminasi teknologi tepat guna berbasis energi terbarukan yakni energi surya, energi angin dan energi biogas yang tak terhubung jaringan PLN off grid untuk fasilitas umum sehingga dapat membantu menciptakan kehidupan masyarakat lebih nyaman.

3. Transfer ilmu pengetahuan dan ketrampilan tentang cara perawatan dan pemeliharaan sistem teknologi energi terbarukan untuk meningkatkan ketrampilan sehingga kesinambungan penerapan teknologi ini tetap terjaga.

\section{Metode Pelaksanaan}

Desa Kiama merupakan salah satu desa yang terletak di wilayah kecamatan Melonguane, Kabupaten Kepulauan Talaud merupakan masyarakat pesisir di pulau perbatasan yang memiliki masalah krisis energi listrik. Masyarakat kepulauan teristimewa pulau Talaud yang dikategorikan daerah 3T (Tertinggal, Terdepan dan Terluar) yang terletak di perbatasan Indonesia dan Filipina perlu mendapat perhatian khusus sejalan dengan program Nawacita. Peta lokasi pulau Talaud yang merupakan pulau terluar yang terletak di daerah perbatasan ditunjukan pada Gambar 1.

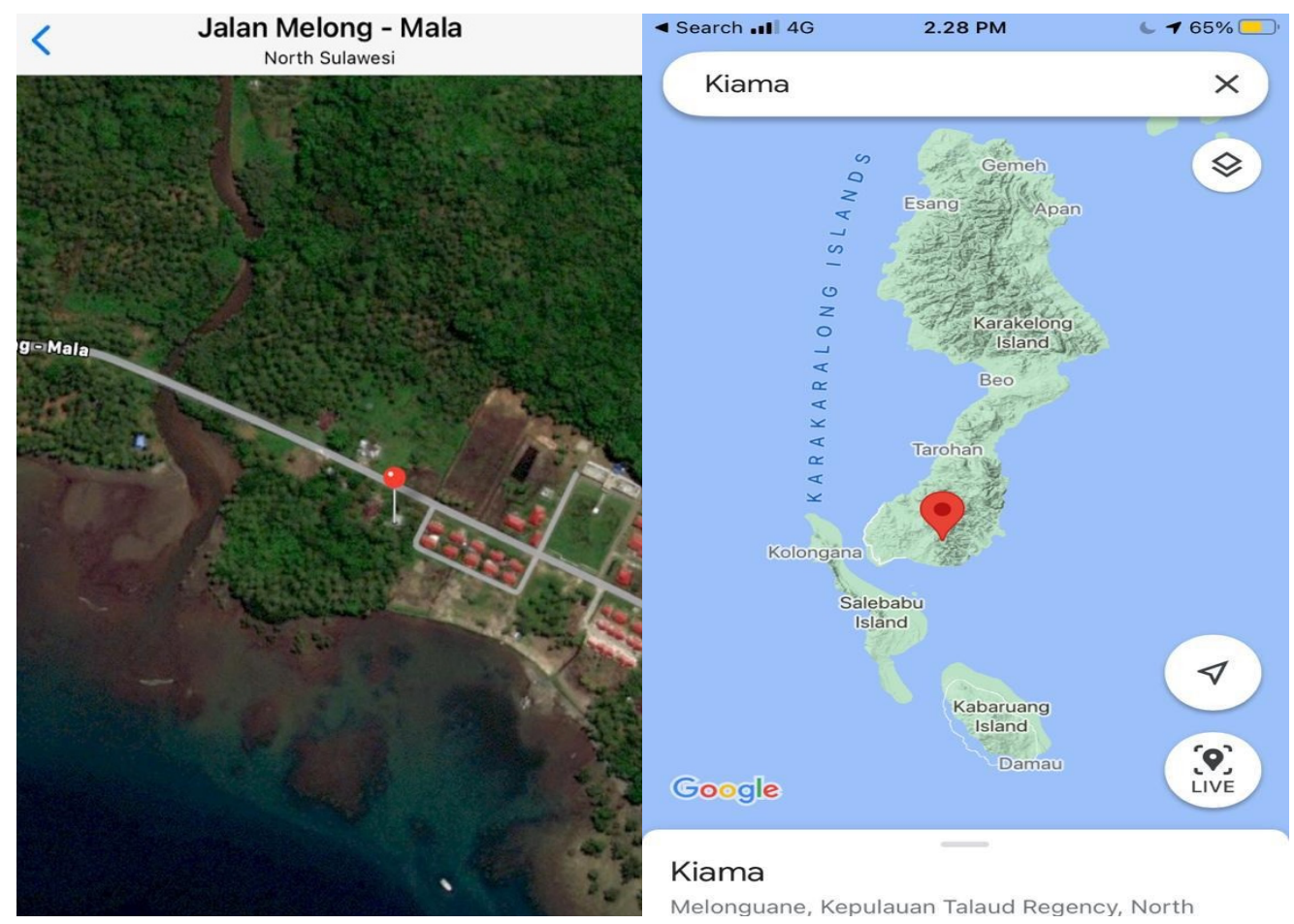

Gambar 1. Lokasi kegiatan pengabdian masyarakat di desa Kiama, Kecamatan Melonguane, Kabupaten Kepulauan Talaud 
Kabupaten Kepulauan Talaud secara geografis terletak pada koordinat 3 $38^{\prime} 00^{\prime \prime}$

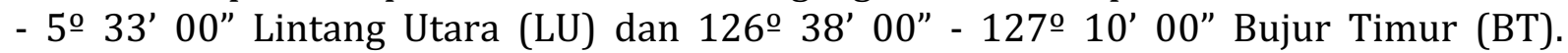
Kabupaten Kepulauan Talaud secara administratif termasuk ke dalam wilayah Provinsi Sulawesi Utara dengan Melonguane sebagai Ibukota Kabupaten. Adapun jarak antara ibukota kabupaten yaitu Melonguane dan ibukota Provinsi Sulawesi Utara yaitu Manado adalah 271 mil laut. Untuk mencapai pulau Talaud dari Pelabuhan Manado dapat menumpang kapal motor dengan waktu tempuh 6 jam atau dengan pesawat udara dengan waktu tempuh 1 jam dari Kota Manado

Nilai strategis pulau Talaud yang merupakan pulau perbatasan antara Indonesia dan Filipina menjadi lokasi penting yang perlu diusulkan dalam PPDM ini. Kepulauan Talaud yang merupakan lokasi desa mitra adalah Pulau terluar di daerah ini sebagaimana ditetapkan dalam Peraturan Presiden RI Nomor 78 Tahun 2005 tentang Pengelolaan Pulau-pulau Kecil Terluar.

Potensi pemanfaatan sumber daya energi desa dan potensi peningkatan sumber daya manusia di desa mitra untuk introduksi teknologi energi terbarukan menjadi tantangan bagi tim pengabdian masyarakat. Metode pelaksanaan program pengembangan desa mitra di desa Kiama Kabupaten Kepulauan Talaud adalah sebagai berikut:

Metode dan Tahapan dalam penerapan teknologi ke masyarakat terdiri dari beberapa tahapan yaitu:

1. Identifikasi kebutuhan masyarakat

Identifikasi kebutuhan masyarakat dilakukan melalui metode survey dan diskusi kelompok terfokus. Melalui survey dan wawancara ke lokasi desa Kiama di Kepulauan Talaud, teridentifikasi kebutuhan desa mitra yang mengalami masalah krisis energi listrik dan kurang pengetahuan akan pemanfaatan potensi energi terbarukan.

2. Perancangan

Perancangan teknologi tepat guna berbasis energi terbarukan berupa penerangan tenaga surya dan pompa air tenaga surya, turbin angin dan biogas berupa gambar sketsa desain.

\section{Pembangunan}

Pembangunan science techno park sebagai site demo dan showcase dari penerapan teknologi tepat guna berbasis energi terbarukan. Pembangunan science techno park melibatkan masyarakat mitra dan tim dalam berkoordinasi untuk membangun science techno park skala kecil yang terpadu di 1 lokasi dan tersebar di beberapa tempat fasilitas umum di desa Kiama berlokasi di sekolah, gereja, mesjid dan jalan setapak umum desa. Science Techno Park yang terletak di 1 lokasi dibangun bersama rumah pelatihan teknologi tepat guna untuk masyarakat dilengkapi dengan fasilitas contoh instalasi penerangan tenaga surya, pompa air tenaga surya, turbin angin, dan biogas.

\section{Pendampingan operasional}

Pendampingan operasional teknologi tepat guna berbasis energi terbarukan berupa tenaga surya, tenaga angin dan tenaga biogas dilakukan Tim pelaksana berupa penyuluhan dan bimbingan teknis melalui pelatihan kepada kelompok mitra pemuda 
desa dan kaum perempuan desa secara langsung di luar jaringan bertempat di rumah pelatihan yang berlokasi di Science Techno Park dan secara dalam jaringan melalui Zoom.

5. Evaluasi Penerapan teknologi tepat guna kepada masyarakat

Evaluasi kegiatan PPDM ini dilakukan melalui wawancara dan survey dengan kelompok mitra dan pemerintah desa mitra yang secara aktif mendukung pelaksanaan PPDM ini. Wawancara dan survey dilakukan melalui media komunikasi dan media sosial mengenai manfaat dan dampak yang dirasakan dengan adanya penerapan teknologi tepat guna.

Faktor yang mendukung pada pelaksanaan PPDM adalah dukungan mitra terhadap tim pelaksana sehingga kegiatan pelatihan dapat berlangung secara online atau dalam jaringan. Pelaksanaan dibantu oleh mahasiswa dan alumni yang berdomisili di lokasi dan dekat lokasi sehingga kegiatan PPDM bisa terlaksana walau ada hambatan jarak dan waktu pandemi.

\section{Hasil dan Pembahasan}

Hasil dan indikator capaian PPDM yang dilakukan kepada mitra dalam rangka pelaksanaan kegiatan pengabdian masyarakat di desa Kiama Kabupaten Kepulauan Talaud adalah sebagai berikut:

1. Pembangunan science techno park berbasis energi terbarukan secara teintegrasi dan satu rumah tahan gempa sebagai contoh implementasi dan tempat pelatihan (Lihat Gambar 2).

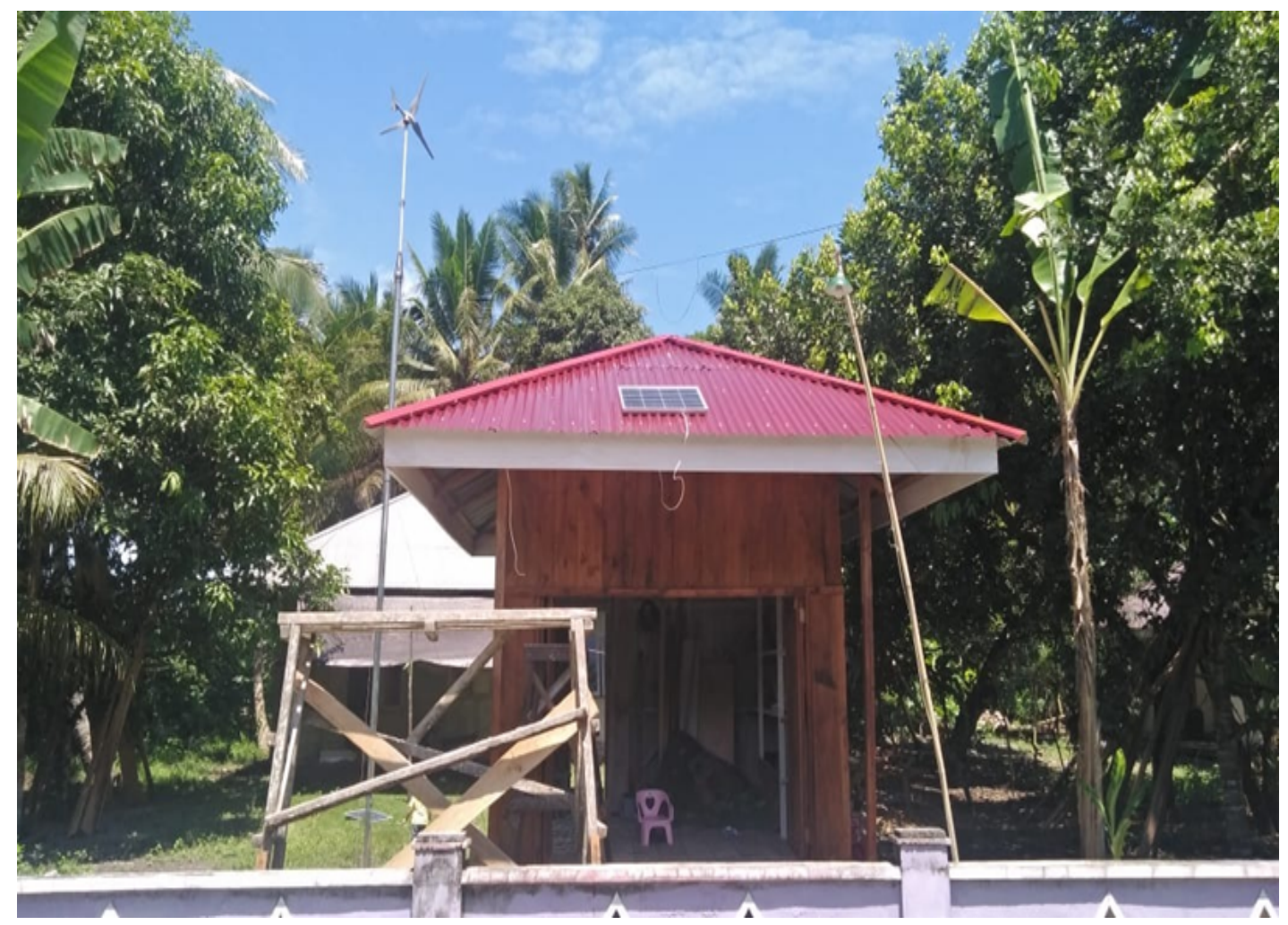

Gambar 2. Pembangunan Science Techno Park dan Rumah Pelatihan Teknologi Energi Terbarukan 
2. Peningkatan pengetahuan masyarakat desa mitra berupa jasa pelatihan dan pendampingan tentang sistem TTG berbasis energi terbarukan yang diterapkan (Lihat Gambar 3).

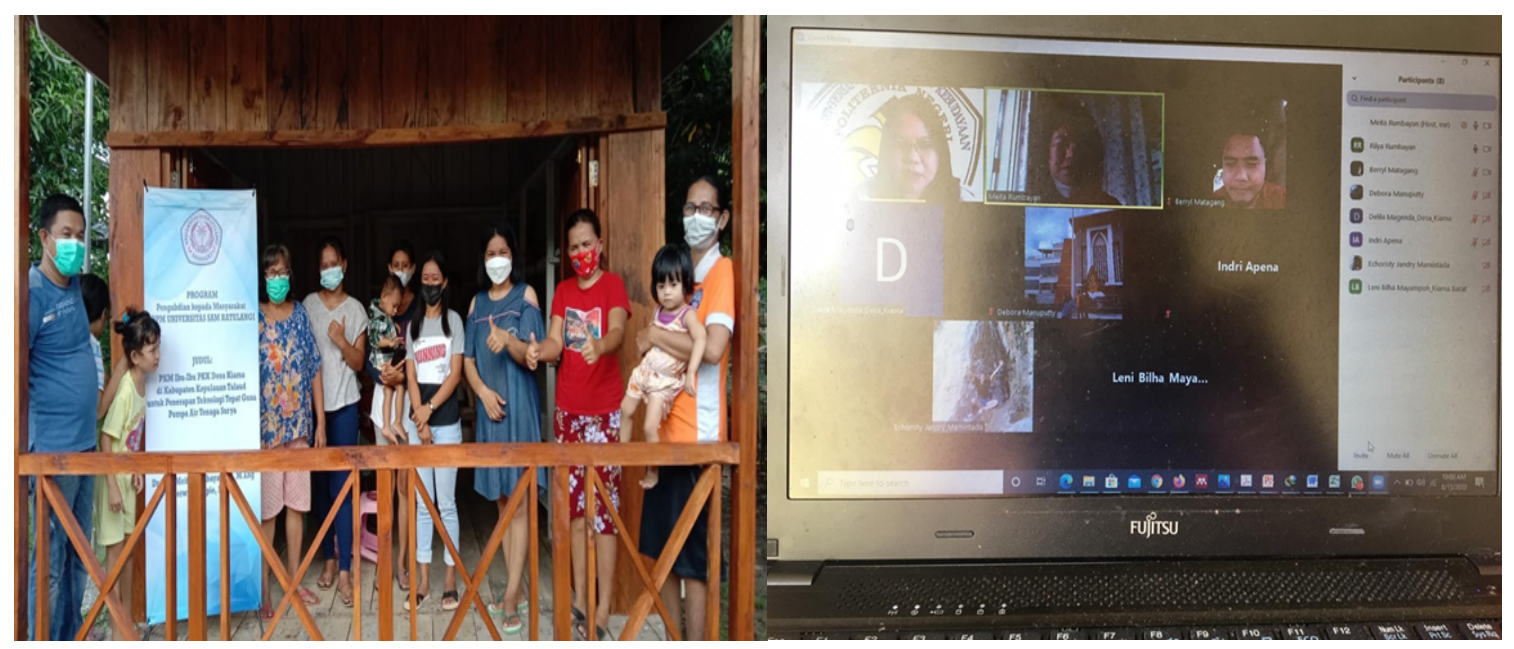

Gambar 3. Pelatihan luring dan daring bagi kelompok perempuan desa dan pemuda desa

3. Penerapan pembangkit listrik tenaga surya skala kecil sebagai diseminasi teknologi energi terbarukan di desa Kiama yang berlokasi di fasilitas umum yaitu gereja, masjid, jalan umum kantor desa, sekolah (Lihat Gambar 4).

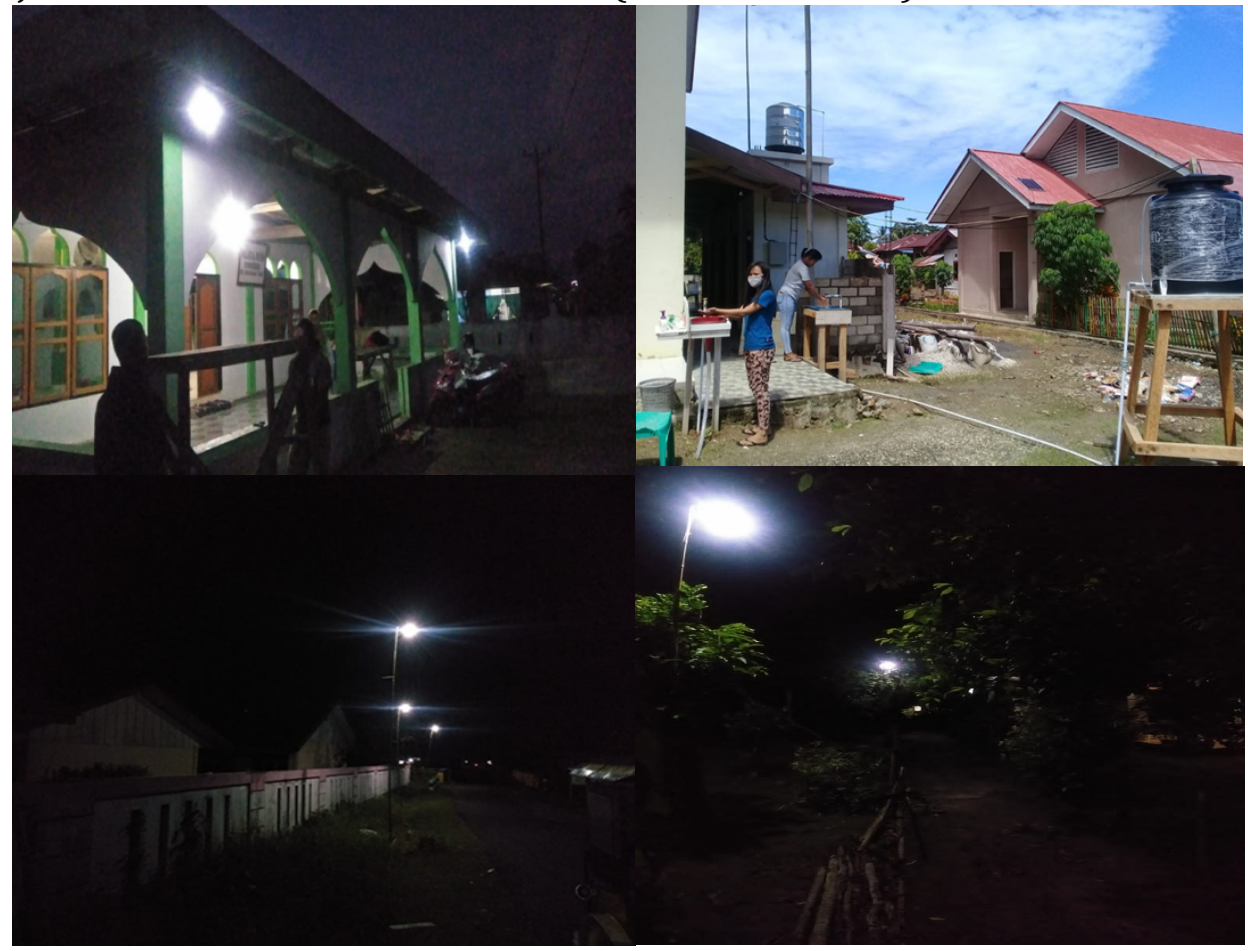

Gambar 4. Penerapan instalasi penerangan tenaga surya di fasilitas umum desa Kiama 
4. Penerapan 2 unit pembangkit listrik tenaga angin skala kecil di lokasi science techno park rumah energi terbarukan (Lihat Gambar 5).

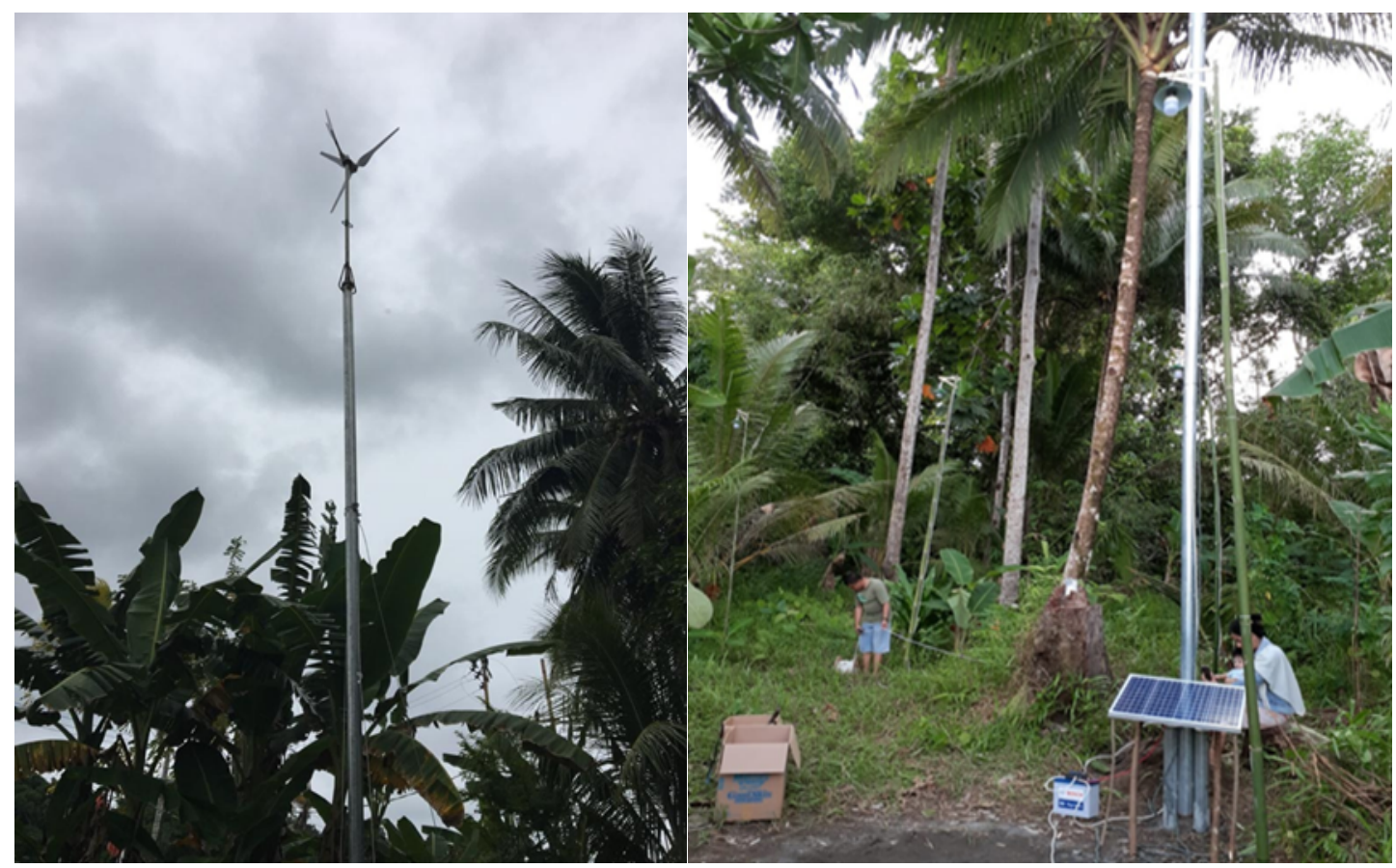

Gambar 5. Penerapan Instalasi Penerangan Tenaga Surya di fasilitas umum desa Kiama

5. Penerapan 1 unit pembangkit listrik tenaga biogas skala rumah tangga sebagai unit contoh (Lihat Gambar 6).

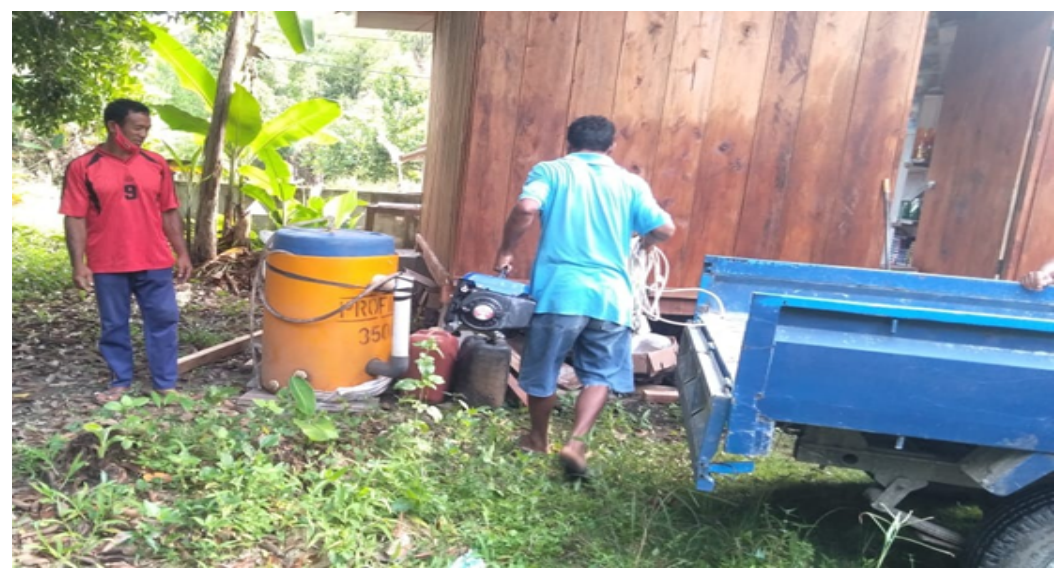

Gambar 6. Penerapan Teknologi Biogas di Desa Kiama

\section{Kesimpulan}

Program pengabdian masyarakat berupa penerapan teknologi energi terbarukan di desa Kiama yang terletak di pulau perbatasan Talaud melalui model terintegrasi di science techno park yang berbasis energi terbarukan dan yang tersebar sebagai contoh di beberapa tempat fasilitas umum dapat tercapai. Program pengembangan desa mitra ini menghasilkan pembangunan 6 unit pembangkit listrik tenaga surya. 2 unit pembangkit listrik tenaga angin dan 1 unit pembangkit listrik tenaga biogas skala rumah tangga. Peningkatan dan pemahaman masyarakat terhadap Teknologi Tepat Guna (TTG) 
berbasis energi terbarukan dilakukan melalui pendampingan tim dan pelatihan secara dalam jaringan (daring) dan luar jaringan (luring) untuk kelompok masyarakat mitra dapat dilaksanakan.

Sebagai rekomendasi, perlu diusahakan keberlanjutan program pengabdian masyarakat di desa mitra yang terletak di pulau perbatasan Talaud sebagai bukti nyata pemerataan pembangunan dan perhatian pemerintah dan civitas akademika kampus sebagai target hilirisasi penelitian. Rekomendasi selanjutnya adalah kegiatan program pengembangan desa mitra perlu dilanjutkan dan dikembangkan menjadi desa mandiri energi dengan prioritas penerapan energi surya.

\section{Ucapan Terimakasih}

Ucapan terima kasih kepada Kementerian Pendidikan, Kebudayaan Riset dan Teknologi untuk dana pengabdian masyarakat yang diberikan sehingga kegiatan Program Pengembangan Desa Mitra (PPDM) di desa Kiama Kepulauan Talaud ini dapat dilaksanakan, juga kepada Lembaga Penelitian dan Pengabdian Kepada Masyarakat (LPPM) Universitas Sam Ratulangi Manado untuk dukungan dalam pelaksanaan kegiatan PPDM.

\section{Referensi}

Khan S, Azad A. K, 2014, Social Impact of Solar Home System in Rural Bangladesh, IAFOR Journal of Sustainability, Energy and the Environment, International Academic Forum, Japan.

Rumbayan, M., Sompie, S. and Nakanishi, Y., 2019. Empowering remote island communities with renewable energy : a preliminary study of Talaud Island. IOP Conference Series: Earth and Environmental Science, 257, p.012024.

Rumbayan, M., Sompie, S., Ruindungan, D. and Panjaitan, N., 2021. Model of solar energy utilization in Bunaken Island Communities. IOP Conference Series: Earth and Environmental Science, 739(1), p.012082.

Rumbayan, M. 2017. Introduksi Teknologi Biogas Sebagai Energi Terbarukan untuk Masyarakat Pedesaan, Ethos (Jurnal Penelitian dan Pengabdian) Vol. 6 no 1, Unisba, Bandung, Indonesia.

Rumbayan, M, Tangkuman, S dan Sompie, S, 2018, Penerapan pembangkit listrik tenaga surya skala rumah sederhana di desa lahopang kabupaten Sitaro Propinsi Sulawesi Utara, Seminar Nasional Penelitian dan Pengabdian Masyarakat, Unisba.

Rumbayan, M., Sompie, S dan Rumbayan, R. 2019. Program Pengembangan Desa Mitra di Kiama Kabupaten Talaud: Penerapan Teknologi Tepat Guna Penerangan Listrik Energi Terbarukan dan Rumah Tahan Gempa, Seminar Nasional Hasil Penelitian dan Pengabdian Kepada Masyarakat 2019, Politeknik Ujung Pandang, Indonesia. Hal. 415-420.

Rumbayan M, Sompie S dan R. Rumbayan, 2021 Program Pengembangan Desa Mitra di Kiama Kabupaten Talaud: Instalasi Pompa Air Tenaga Surya, SHARE (Journal of Service Learning), Vol. 7, No. 2, August 2021, 73-77 https://share.petra.ac.id/index.php/share/article/view/22979/20410 
Rumbayan M, Sompie S dan R Rumbayan, 2021 Penerapan Teknologi Tepat Guna berbasis Energi Terbarukan di desa Kiama Kabupaten Kepulauan Talaud, Vol 1 No 2 (2020): Jurnal Pengabdian Masyarakat https://jurnal.stie.asia.ac.id/index.php/jpm/article/view/297/135

Rumbayan M, 2020, Diseminasi Pembelajaran Energi Terbarukan Turbin Angin Pada Masyarakat di Desa Kiama Kepulauan Talaud, $\quad$ Vol 3 No 3 (2020): IKRAITHABDIMAS VOL 3 NO 3 BULAN NOVEMBER 2020. 